\title{
PERANCANGAN DAN IMPLEMENTASI PENAMPIL NAMA STASIUN UNTUK KERETA API LOKAL BERBASIS MIKROKONTROLLER DENGAN DISPLAY DOTMATRIX
}

\author{
Hari Satriyo Basuki \\ Pusat Penelitian Informatika, Lembaga Ilmu Pengetahuan Indonesia \\ Jl. Cisitu 21/154 D Bandung 40135
}

\begin{abstract}
As we know that in the lokal train, sometimes we need information what station in front or already left. In this paper will be discussed about the design and the implementation of a lokal train station name displayer using microcontroller and LEDs. dot matrix. This display should be informative especially for new passengers or passenger who sleep during this travel and also for foreigners. This display will be place in parallel in every wagon near the door. To select the name of the stations is only by pressing the switch which is connected to every controller in the displayer.

Keywords : station name displayer, microcontroller, dotmatrix display
\end{abstract}

\section{PENDAHULUAN}

Kereta api lokal seperti KRD di Bandung dan di Jakarta (Jabotabek) yang menggunakan kereta Rel Listrik maupun Lokomotif diesel dapat dilengkapi dengan penampil nama stasiun. Dalam aplikasinya dibuat sesederhana mungkin akan tetapi cukup kuat untuk menerima keadaan yang membuat peralatan bisa rusak seperti goncangan, suhu yang cukup tinggi, debu yang banyak serta tegangan yang kurang stabil. Untuk kereta lokal Bandung akan selalu berangkat pergi dari ujung ke ujung yaitu dari Padalarang sampai Cicalengka dan kembali lagi dari Cicalengka ke Padalarang. Peralatan ini diperlukan bagi orang yang belum tahu nama stasiun yang akan dihadapi berikutnya walau mungkin bisa melihat jalur perjalanan akan tetapi sebagai alat bantu akan lebih memudahkan dalam perjalanannya. Dalam rancangan ini dipergunakan keypad untuk pemilihan nama stasiun yang ada di depan dan yang di belakang.

Tampilan stasiun yang akan didatangi kereta dan yang baru saja dilewati dapat didisplaykan dengan menggunakan dot matrix dan jalur kereta seyogyanya tertempel di atas pintu. Operator atau masinis hanya menekan tombol yang ditentukan untuk menampilkan nama stasiun yang dikehendaki ditampilkan.

\section{PROSES PERANCANGAN}

Dalam perancangan sistem penampil ini direncanakan menggunakan komponen-komponen yang banyak dipasaran yaitu Mikrokontroller 89C51, EPROM, Keypads, IC Driver, Dot Matrix Display. Secara block diagram sebagai di bawah ini. 


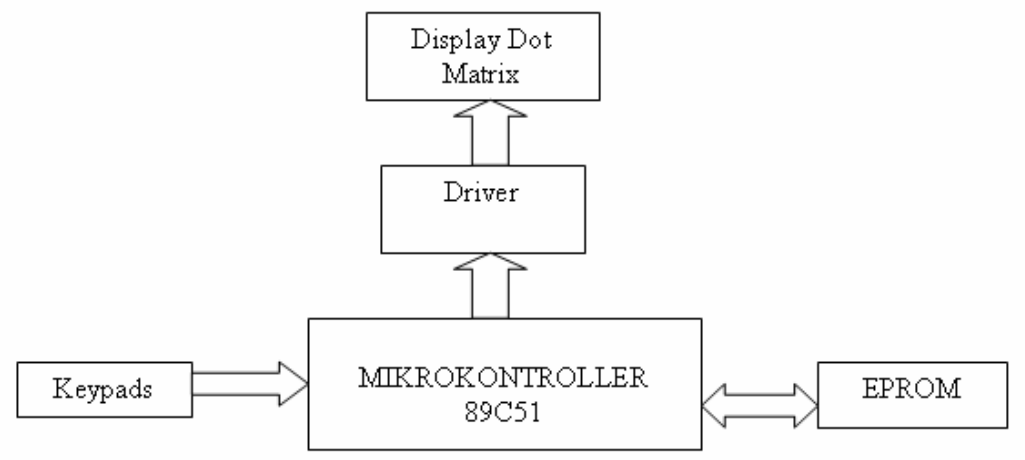

Gambar 1. Block diagram perancangan

Keypads adalah suatu peralatan berupa tombol-tombol yang dapat memberikan logika-logika yang akan diproses oleh mikrokontroller. Dalam perancangannya setiap tombol mewakili satu nama stasiun sehingga tombol tersebut dipergunakan untuk memilih nama stasiun yang dikehendaki tertampil.

EPROM adalah IC yang berfungsi untuk menyimpan piranti lunak (program memory) yang menjalankan proses pengendalian Mikrokontroller. Mikrokontroller adalah sebuah chip IC yang terdiri dari beberapa Port, Control Unit, ALU, Memory. Port-2 tersebut dipergunakan sebagai masukan, keluaran dan hubungan ke memory. IC mikrokontroller ini berfungsi untuk mengendalikan sistem yang ada.

Driver adalah peralatan yang untuk menghubungkan antara keluaran mikrokontroller dengan Display Dot Matrix. Display dot Matrix adalah peralatan yang digunakan untuk menampilkan keluaran dijital dari Driver dan dot matrix ini berupa sekumpulan LED yang disusun secara matrix untuk menampilkan nama stasiun yang dipilih melalui tombol/Keypads. Dalam implementasinya digunakan 7 buah Dot Matrix display dimana diharapkan sudah dapat menampilkan nama semua stasiun Kereta api yang dilewati kereta lokal di Bandung. Nama-nama stasiun di Bandung pada Tabel 1 berikut:

Tabel 1. Nama-nama stasiun kereta lokal di Bandung

\begin{tabular}{|c|l|l|c|l|l|}
\hline No & Nama Stasiun & $\begin{array}{c}\text { Tampilan } \\
(7 \text { HURUF })\end{array}$ & No & Nama Stasiun & $\begin{array}{c}\text { Tampilan } \\
(7 \text { HURUF })\end{array}$ \\
\hline 1 & Padalarang & PLARANG & 8 & Cikuda Patueh & CIKUDAP \\
\hline 2 & Gado Bangkong & GADO B & 9 & Kiara Condong & KIRCON \\
\hline 3 & Cimahi & CIMAHI & 10 & Gede Bage & GBAGE \\
\hline 4 & Cimindi & CIMINDI & 11 & Cimekar & CIMEKAR \\
\hline 5 & Andir & ANDIR & 12 & Rancaekek & RNCEKEK \\
\hline 6 & Ciroyom & CIROYOM & 13 & Haur Pagur & HAURPG \\
\hline 7 & Bandung & BANDUNG & 14 & Cicalengka & CICALNK \\
\hline
\end{tabular}




\subsection{Piranti Keras}

Piranti keras dirancang dengan menggunakan Papan Rangkaian Tercetak PCB acrylic. Sebelumnya dicoba dengan menggunakan papan berlubang dan wire wrap dimana bila dengan simulasi LED sudah menyala seperti yang diinginkan maka baru digambar dengan menggunakan piranti lunak Protel [1].

\subsubsection{Rangkaian Pengendali}

Dalam perancangannnya untuk Rangkaian Pengendali digunakan mikrokontroller buatan Atmel seri 89C51 [2] yang menggunakan kristal pasif 12 Mhz untuk clocknya. Mikrokontroller ini mempunyai port-port dan pembacaan saklar Keypads yang ditekan melalui encoder akan masuk ke Port 1. Mikro ini akan memproses keypads nomor berapa yang ditekan dan memproses datanya sesuai dengan program yang dibuat. Port 1 merupakan Port masukan/keluaran (I/O) yang bekerja secara bergantian antara proses scanning, pemberian sinyal pada baris serta pembacaan keypads. Pembacaan sinyal yang dikirimkan keypads akan diatur oleh tri state buffer untuk dihubungkan ke Port 1. Tri State buffer berfungsi sebagai saklar yang hanya akan aktif saat proses pembacaan keypads oleh mikrokontroller dimana untuk mengaktifkannya menggunakan sinyal RD di Mikrokontroler yang dihubungkan dengan enable $1 \mathrm{G}$ dan $2 \mathrm{G}$.

Port 0 dari mikrokontroller 89C51 digunakan sebagai data bus yang akan berfungsi sebaga bus data. Selain sebagai bus data maka Port 0 ini juga digunakan untuk 8 bit bus alamat bawah ditambah dengan Port 2 sebagai alamat bit atas sehingga akan terbentuk 16 bit alamat. Port 0 dihubungkan dengan latch untuk menyimpan data alamat bawah sementara karena data tidak dapat dikirimkan secara bersamaan melalui dua buah port. Dengan demikian saat data alamat atas dikirimkan maka EPROM dapat menerima secara bersamaan data alamat bawah dan atas. Latch ini diaktifkan atau tidak diaktifkan dengan mengirimkan sinyal low dari pin ALE di Mikrokontroller ke pin LE di IC Latch.

Mikrokontroller 89C51 mempunyai memory didalamnya akan tetapi kapasitasnya kurang besar untuk menampung piranti lunak yang akan mengerjakan sistem ini. Oleh karena itu dipasanglah EPROM diluar Mikrokontroller. Selain itu ada keuntungan lain dengan dipergunakannya memory luar ini yaitu mencegah rusaknya mikrokontroller bila memory internal di dalam mikrokontroller terlalu sering dihapus dan diisi. Dengan dipergunakan memory external maka pengembangan dan modifikasi sistem akan lebih mudah karena hanya dengan memodifikasi programmnya. Untuk mengaktifkan dan menon-aktifkan program dalam memory external ini dengan cara mengirimkan sinyal High dari pin PSEN di mikrokontroller ke OE di EPROM dan agar dapat mengakses program di EPROM external tersebut pin EA di mikrokontroller dihubungkan ke ground.

\subsubsection{Rangkaian Keypads}

Pemilihan nama stasiun yang akan ditampilkan di peraga display dot matrix dilakukan dengan menekan salah satu saklar pushed on. Untuk menghasilkan 
rangkaian keypads sesuai dengan yang diinginkan diperlukan 2 buah enkoder. Rangkaian ini terdiri dari 14 buah saklar pushed on dan 2 buah enkoder 8 to 3 line.

\subsubsection{Rangkaian Display}

Karena akan mendisplaykan huruf dan menghindari pemakaian display hex maka direncanakan akan menggunakan display dot matrix $5 \times 7$ dot dimana diharapkan dapat dibentuk huruf yang diperlukan untuk menampilkan semua stasiun. Dot Matrix ini terdiri dari 35 titik (dot) dimana tiap dot adalah LED yang akan menyala sesuai dengan program yang dikehendaki/dibuat. Walau tidak sempurna penunjukannya akan tetapi karakter atau huruf yang didisplaykan diharapkan akan sudah dapat dibaca. Untuk mengendalikan display ini diperlukan rangkaian Driver yang mengubah kode-kode yang diberikan oleh mikrokontroller melalui Port 1 sehingga secara scanning pada kolom (35 buah) dan pemberian sinyal (7 buah) akan tertampil huruf yang dikehendaki. Port 1 yang terdiri dari 8 bit diubah oleh decoder menjadi 35 bit dengan menggunakan beberapa buah decoder.

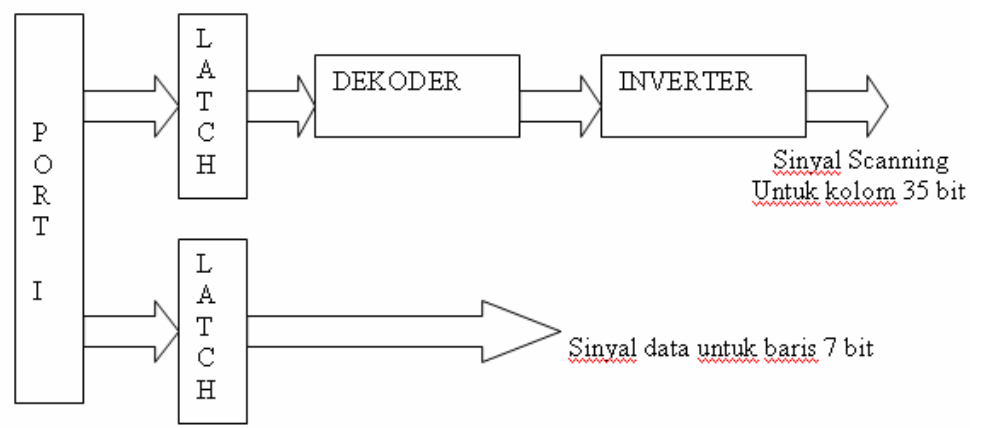

Gambar 2. Blok diagram rangkaian proses scanning

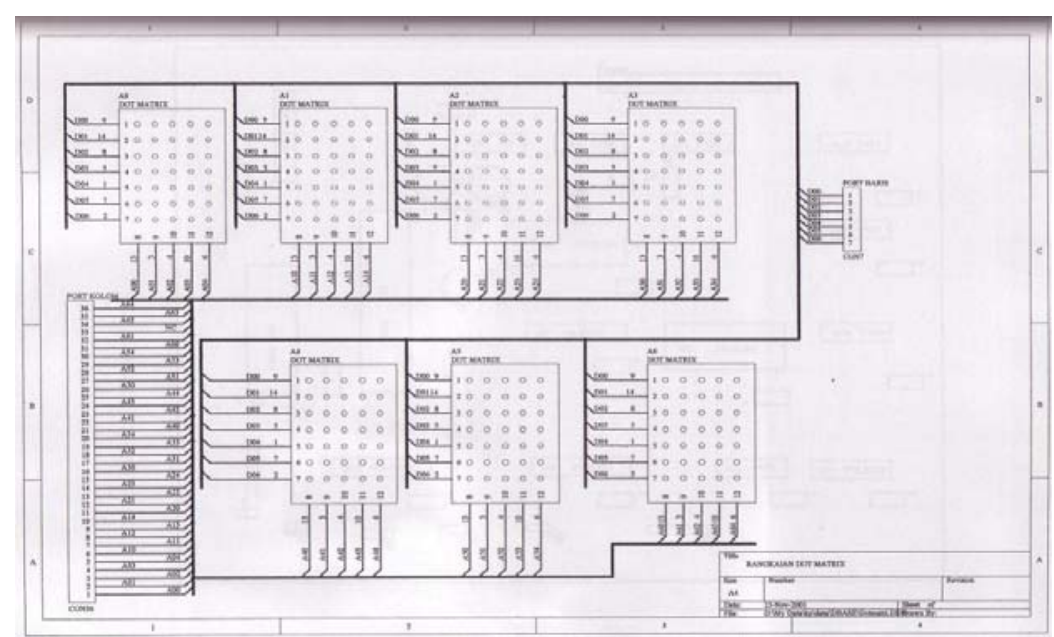

Gambar 3. Rangkaian dot matrix 


\subsection{Piranti lunak}

Piranti keras yang dirancang menggunakan mikrokontroller 89C51 memerlukan piranti lunak sebagai pengolah dan pengendali mikrokontroller tersebut. Piranti lunak ini disimpan didalam EPROM eksternal. Direncanakan program yang akan dibuat akan menggunakan assembler yang disusun dengan bantuan program Franklin Software Inc [3]. Didalam Franklin Software ini telah tersedia fasilitas compile, debug, serta simulasi untuk piranti lunak yang telah dibuat.

Secara garis besar dalam perencanaannya program pengendali mikrokontroller ini dibagi menjadi 3 tahap yaitu :

- $\quad$ Bagian pembaca data dari Keypads

- $\quad$ Bagian pemrosesan data

- $\quad$ Bagian penampil data pada dot matrix

\section{IMPLEMENTASI RANCANGAN}

\subsection{Rangkaian piranti keras}

Setelah dicoba di papan percobaan dengan wire wrap dan berjalan dengan baik maka dibuatlah papan rangkaian tercetaknya (PCB) dengan menggunakan Protel. Hasil autorouting di protel diprint dan diproses secara kimia sehingga menjadi papan rangkaian tercetak dengan menggunakan bahan fiber glass. Ada tiga papan yaitu :
a. Papan Pengendali dot matrix berisi mikro, EPROM dan lainnya (Gambar 4)
b. Papan keypads dengan encoder (Gambar 5)
c. Papan LEDs Dot Matrix display/peraga (Gambar 6)

Ketiga papan tersebut dihubungkan dengan menggunakan kabel pelangi dan pin-pin penghubung atau konektor. Untuk bagian keypads dan display digunakan papan berlubang-lubang karena lebih cepat dan lebih murah. (Gambar 7)

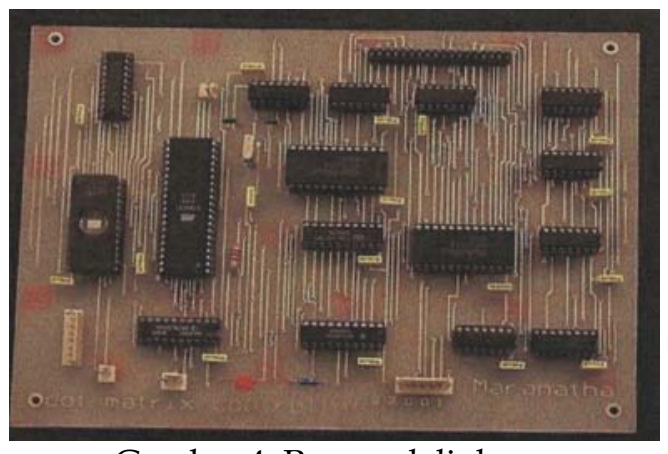

Gambar 4. Pengendali dengan Mikrokontroller dan EPROM dan lainnya

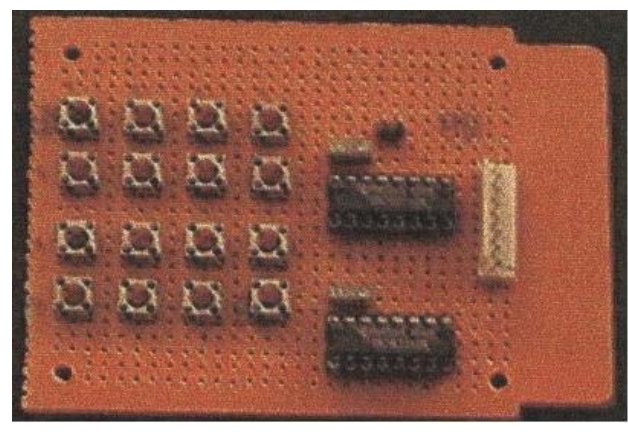

Gambar 5. Keypads dan encoder 


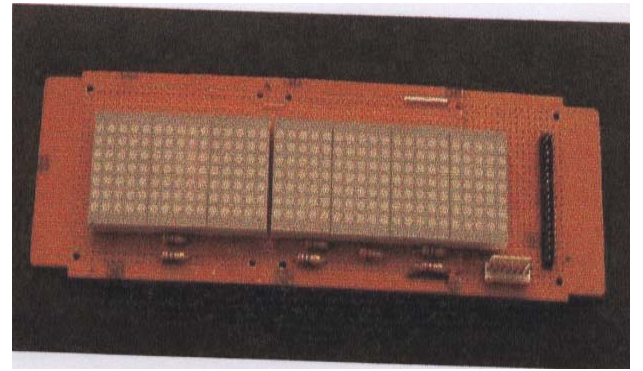

Gambar 6. LEDs Dot Matrix Display

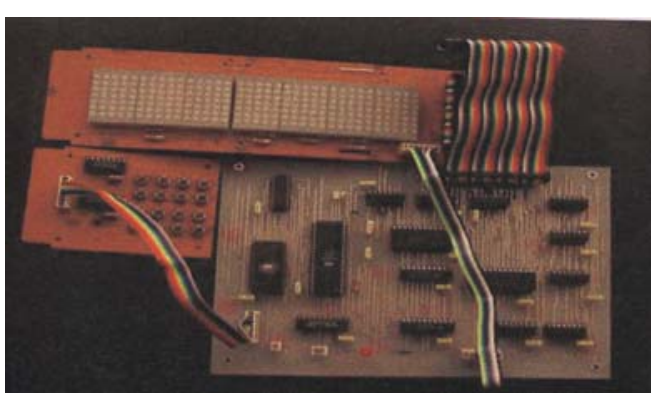

Gambar 7. Ketiga Papan terangkai

\subsection{Piranti lunak}

Piranti lunak yang dibuat untuk mengendalikan mikrokontroller dibuat dengan menggunakan bahasa Assembler dengan flowchart utama pada Gambar 8 di bawah ini :

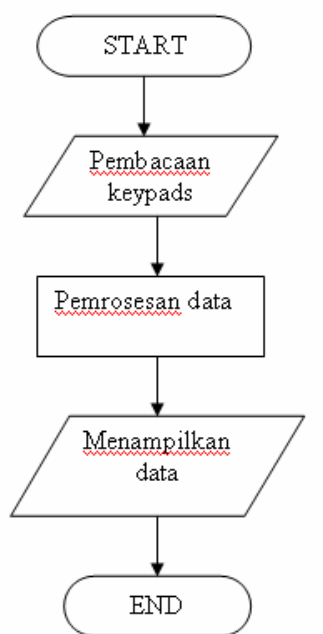

Gambar 8. Flowchart dasar

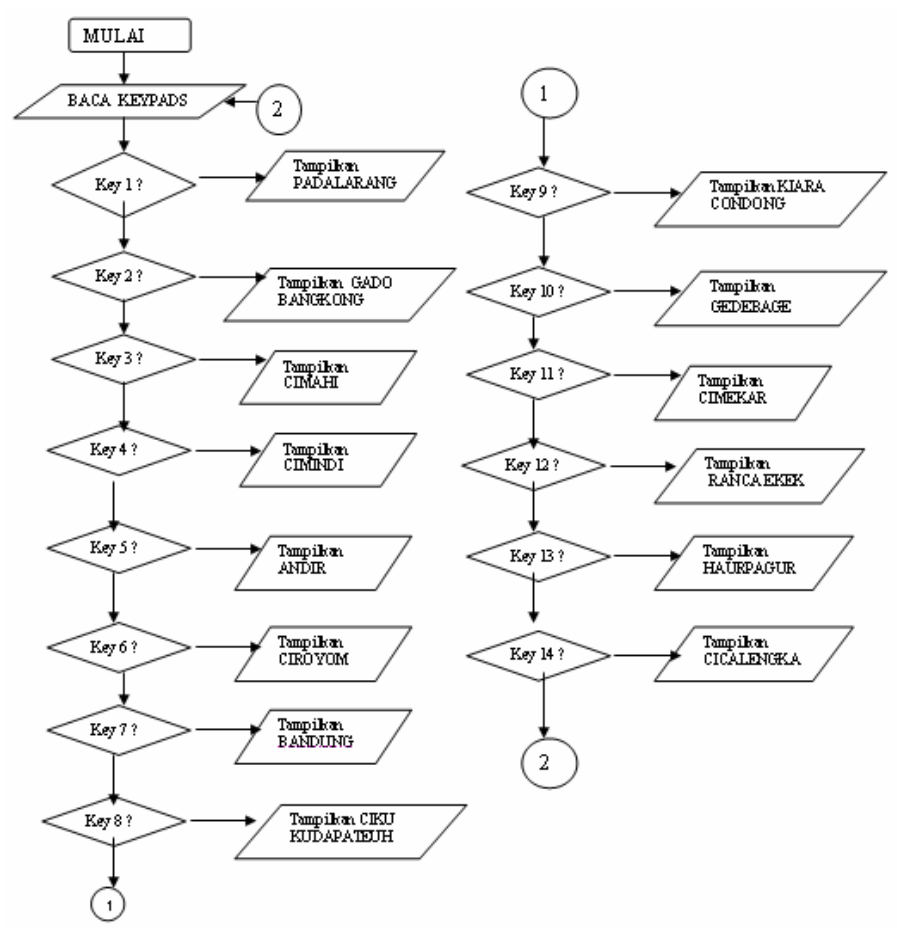

Gambar 9. Flowchart pembacaan Keypads

\subsubsection{Subprogram Pemrosesan Data}

Data yang dibaca dari penekanan Keypads melalui Port 1 disimpan dalam akumulator (Register A) dan kemudian data tersebut diproses. Kombinasi kode dari masing masing tombol keypads yang ditekan hanya menggunakan 6 bit dari 8 bit yang ada pada Port 1 . Oleh karena itu 2 bit sisanya tidak digunakan dan harus diberi filter agar tidak mengganggu data yang akan diproses. Untuk filter data ini digunakan perintah logical operations yaitu ANL. Program akan 
menginterpretasikan tombol mana yang ditekan pada keypads dengan memanggil subprogram yang sesuai dengan data dari keypads dan selama tidak ada tombol yang ditekan pada keypads maka program akan terus membaca data dari keypads. Perintah yang digunakan untuk memilih adalah CJNE (Compare Jump Not Equal) yang membandingkan data pada Akumulator (Register A) dengan data yang diinginkan dimana bila tidak sama akan meloncat pada program yang telah ditentukan lokasinya.

\subsubsection{Menampilkan data pada Dot Matrix}

Setelah subprogram yang diinginkan dipanggil maka langkah selanjutnya adalah menampilkan data nama stasiun yang sesuai dengan masukan atau penekanan pada keypads. Data yang akan ditampilkan oleh peraga dot matrix juga dikendalikan dan dikirim melalui port 1 dimana karena Port 1 ini juga sebagai jalur masukan dari keypads dan sebagai jalur keluaran dari mikrokontroller maka saat mengirimkan data dari mikrokontroller rangkaian keypads harus dalam keadaan tidak aktif. Dalam menampilkan deretan huruf nama stasiun pada dot matrix perlu dilakukan secara bergantian karena menggunakan proses scanning. Hal ini adalah karena menghemat dan keterbatasan Port di Mikrokontroller 89C51. Proses scanning adalah proses dimana penyalaan LEDs atau dot di dot matrix dilakukan bergiliran satu per satu. Setelah mengirim data untuk kolom maka selanjutnya mengirim data untuk baris dan dari huruf satu setelah lengkap bergeser dan menampilkan huruf kedua hingga membentuk sebuah nama stasiun.

Misalkan ditekan Keypads nomor 1 dimana akan menampilkan stasiun Padalarang dengan tampilan PLARANG maka pertama akan muncul huruf $\mathrm{P}$ kemudian $\mathrm{P}$ bergeser ke kiri dan tempat huruf $\mathrm{P}$ akan digantikan dengan huruf $\mathrm{L}$. Kemudian $\mathrm{P}$ dan $\mathrm{L}$ akan bergeser kekiri dan tempat $\mathrm{P}$ dan $\mathrm{L}$ ditempati oleh huruf A dan R. Demikian seterusnya hingga tertampil PLARANG secara keseluruhan sehingga terbaca PLARANG yang berarti Padalarang. Demikian pula untuk menampilkan stasiun yang lain.

Gambar 10 berikut adalah hasil display dua stasiun, BANDUNG dan GADO BANGKONG

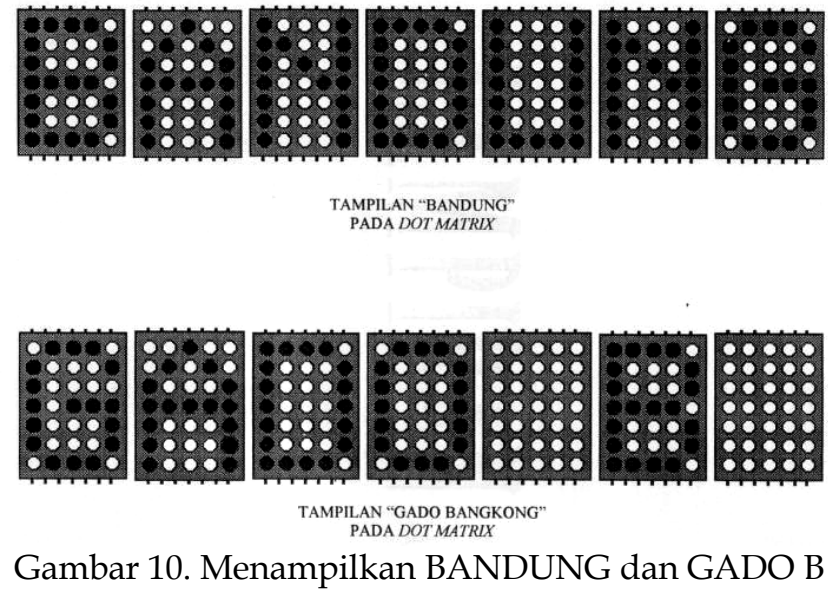




\section{ANALISA RANGKAIAN}

Beberapa komponen ternyata kurang tepat dan memerlukan penggantian dan kelihatannya rusak dari pabriknya seperti decoder 74LS154 dan 74LS373 [4] dan juga beberapa LEDs pada Dot Matrx juga tidak menyala. Dengan cara diganti dan dicoba lagi maka rangkaian secara keseluruhan berjalan sesuai dengan yang dikehendaki. Karena kesalahan kabel dapat menyebabkan rangkaian di wire wrap tidak berjalan. Walau secara analisa rangkaian sudah benar akan tetapi kemungkinan kesalahan penyambungan dan kesalahan komponen dapat terjadi.

Ketidak-baikan komponen memang sering terjadi di Indonesia yang disebabkan karena komponen yang masuk ke Indonesia banyak yang tidak lolos uji dan dibeli secara kiloan.

\section{PENGUJIAN}

Bila Perangkat keras sudah diuji dengan menggunakan wire wrap dan PCB berlubang dan perangkat lunaknya sudah diuji dengan menggunakan Franklin Software, seperti pada Gambar 11 berikut :

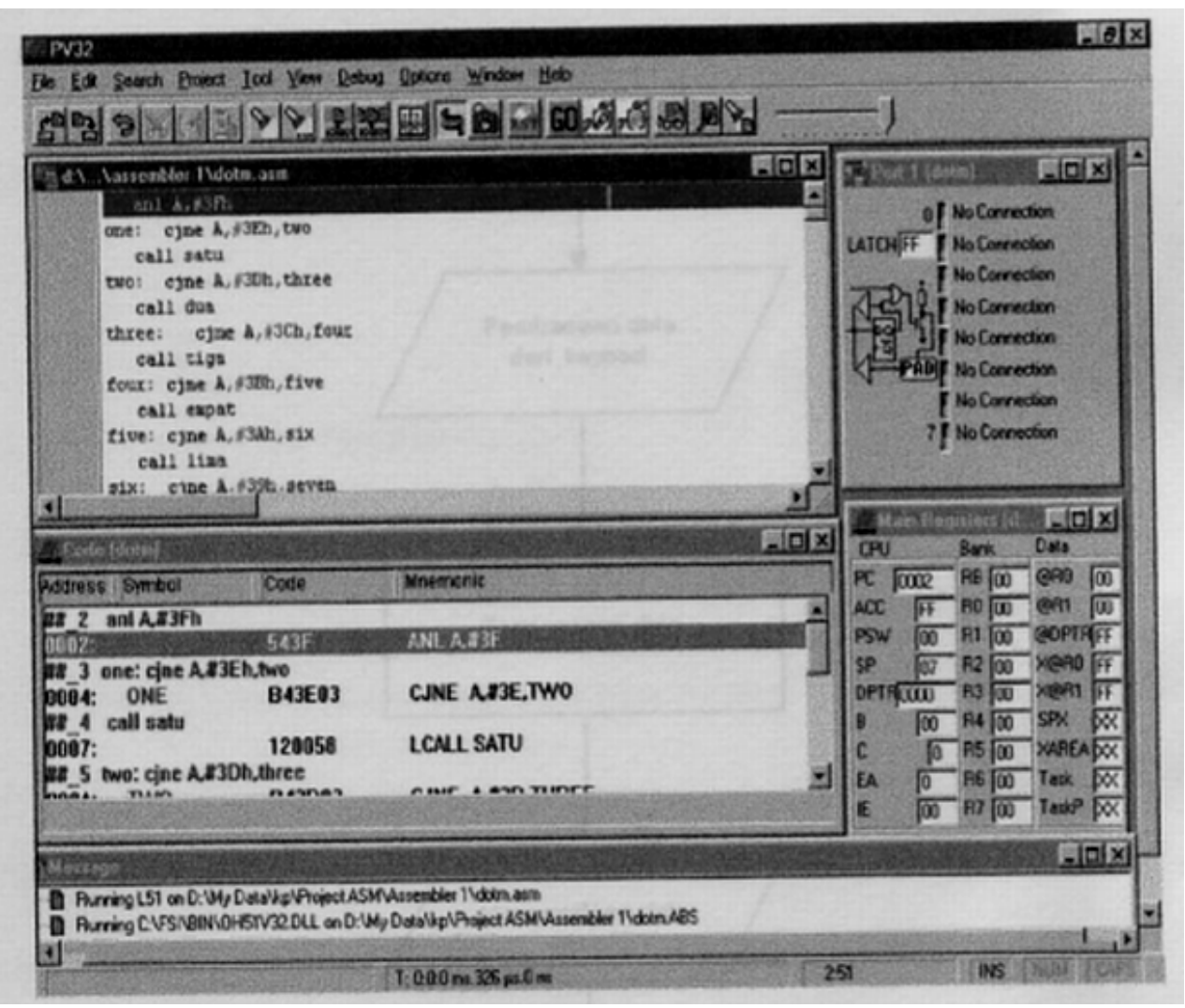

Gambar 11. Tampilan hasil pengetesan dengan Franklin Software 
Dalam keadaan module perangkat keras ( 3 buah) terhubung semua dan EPROM sudah diisi tanpa kesalahan maka rangkaian diberi tegangan dan dicoba menekan Keypads nomor 1 sampai 14 dan dilihat yang tertampil di dot matrix. Dan dalam pengujian ternyata semuanya berjalan sesuai dengan yang dikehendaki. Tertampil nama stasiun Padalarang dengan tampilan PLARANG bila skakelar 1 pada modul Keypads ditekan, tertampil nama stasiun Andir dengan tampilan ANDIR bila skakelar 5 pada modul Keypads ditekan, dan tertampil nama stasiun Cicalengka dengan tampilan CICALNK bila skakelar 14 pada modul Keypads ditekan dan lainnya. Maka diperlukan rangkaian antar muka yang menghubungkan antara mikrokontroller dengan display.

\section{SIMPULAN}

Dalam pembuatan peraga nama stasiun ini dapat disimpulkan bahwa dengan menggunakan mikrokontroller dan proses scanning serta menggunakan dot matrix dapat menampilkan nama nama stasiun dengan cukup jelas.

Dari hasil yang telah dibuat dapatlah dikembangkan pada tahap selanjutnya antara lain :

a. Skakelar dapat diletakkan di bagian masinis sehingga tidak semua orang dapat memindahkan nama stasiun atau menekan untuk mengganti nama stasiun. Sedangkan peraga nama stasiunnya dapat diparalel dan diletakkan di tiap gerbong. Board skakelar hanya satu dengan dua buah peraga ditiap gerbong. Tentunya memerlukan sedikit perubahan dalam perangkat lunak dan perangkat kerasnya dalam implementasinya.

b. Dapat diberi fasilitas RS-232 untuk merubah nama stasiun on line, dengan menggunakan beberapa port sebagai komunikasi serial sehingga bias mengup-load program yang dibuat di PC ke Mikrokontroller.

c. Dapat digabungkan dengan GPS dan dihubungkan dengan EPROMnya sehingga diprogram pada setiap lokasi yang terdeteksi oleh GPS maka akan menampilkan nama stasiun secara otomatis, tanpa menekan skakelar.

d. Dapat digabungkan dengan announciator sehingga bila peraga menampilkan nama stasiun maka akan terdengar suara yang menyatakan bahwa stasiun berikutnya adalah nama yang tertampil tersebut.

e. Penambahan peraga dot matrix sejumlah yang diperlukan untuk agar dapat menampilkan nama stasiun secara lengkap tidak dipotong/disingkat.

f. Keuntungan dipergunakannya panampil ini adalah untuk para penumpang yang baru pertama kali menggunakan KRD ini, untuk warga asing yang belum hapal nama stasiun dan bagi yang tertidur diperjalanan kereta tersebut. Alangkah baiknya bilamana ditambah dengan suara bel pada setiap penggantian nama stasiun atau suara yang direkam pada memory dan terdengar melalu pengeras suara. 


\section{UCAPAN TERIMA KASIH}

Terima kasih yang tak terhingga penulis sampaikan kepada Saudara Slamet Gandiwidjaja dan Sdr. Herman Susilo Haslim, dua orang mahasiswa dari Universitas Kristen Maranatha Bandung Jurusan Teknik Elektro yang telah membantu merealisasikan penelitian saya ini.

\section{PUSTAKA}

[1] Putro A.P. Belajar Mikrokontroller AT89C51/52/53, Teori dan Aplikasi, Edisi 2, Penerbit Gava Media

[2] . Advanced Development System Version 6.0 for 8051, Franklin Software Inc

[3] . (1989) Linear Data Book 2, National Semiconductor Corporation

[4] . Programming and Interfacing, Wesley Publishing

[5] . Electronic CAD for Engineers, Protel 